Development of polymorphic microsatellite markers of the Seychelles endemic tree Glionnetia sericea (Rubiaceae)

Journal Article

Author(s):

Finger, Aline; Kaiser-Bunbury, Christopher N.; Kettle, Chris J.

Publication date:

2012-06

Permanent link:

https://doi.org/10.3929/ethz-b-000048862

Rights / license:

In Copyright - Non-Commercial Use Permitted

Originally published in:

Conservation Genetics Resources 4(2), https://doi.org/10.1007/s12686-011-9515-3 


\title{
Development of polymorphic microsatellite markers of the Seychelles endemic tree Glionnetia sericea (Rubiaceae)
}

\author{
Aline Finger $\cdot$ Christopher N. Kaiser-Bunbury • \\ Chris J. Kettle
}

Received: 24 August 2011/Accepted: 28 August 2011/Published online: 9 September 2011

(C) Springer Science+Business Media B.V. 2011

\begin{abstract}
Glionnetia sericea (Rubiaceae) is an endemic and rare tree species of the Seychelles, restricted to altitudes between 500 and $900 \mathrm{~m}$ with less than 1,000 remaining individuals. It survives in mist forests but also in smaller populations on granitic outcrops (inselbergs) and is pollinated by hawk moths which might ensure long-distance pollen flow. Understanding the reproductive ecology of this species will allow a better understanding on how such species survive in naturally fragmented habitats and will provide scientifically informed management recommendations. Here we report on ten species specific polymorphic microsatellite loci developed for a study of historic and contemporary gene flow. Based upon a sample of 81 adults, the number of alleles per locus ranged from 3 to 12 (mean of 6.1 per locus) with an average polymorphic information content of 0.52 across loci. Expected heterozygosity ranged from 0.27 to 0.82 with two of ten primers showing some deviation from Hardy-Weinberg expectation.
\end{abstract}

Keywords Microsatellites - Glionnetia sericea .

Population genetics $\cdot$ Seychelles $\cdot$ Gene flow

The rare tree Glionnetia sericea (Rubiaceae) is endemic to the Seychelles archipelago. It is found on two Islands, Mahé and Silhouette, where probably less than 1,000 individuals survive at ten known discrete sites. The species

A. Finger $(\bowtie) \cdot$ C. N. Kaiser-Bunbury · C. J. Kettle

ETH Zürich, ITES-Ecosystem Management,

Universitätsstrasse 16, 8092 Zurich, Switzerland

e-mail: aline.finger@env.ethz.ch

C. N. Kaiser-Bunbury

Department of Bioscience, Genetic and Ecology Group,

Aarhus University, 8000 Aarhus C, Denmark is classified as vulnerable in the IUCN red list (2011). G. sericea is distributed in mist forests at higher altitudes between $500 \mathrm{~m}$ and $900 \mathrm{~m}$ and is representative of a plant community occurring in remnants of virgin forest. The current distribution includes some relatively large and continuous populations, consisting of more than 100 individuals, and some smaller more isolated populations found on granitic outcrops (inselbergs). Increase in habitat degradation and invasive species may threaten the long-term survival of this species (Daehler et al. 2004) and the inselbergs provide important refugia for Glionnetia sericea. The species' naturally patchy population structure on inselbergs provides a useful study system for investigations of the genetic consequences of habitat fragmentation. Seeds are dispersed by wind and it is pollinated by hawk moths (Agrius convolvuli and Cenophodes tamsi) (KaiserBunbury et al. 2011), traits that might render the species less vulnerable to habitat fragmentation.

Our work aims to investigate the ability of this species to survive in fragmented populations through a better understanding of its reproductive ecology and specifically, historic genetic differentiation, contemporary gene flow by pollen dispersal, and genetic diversity among remaining large continuous and small isolated populations.

Here we describe the characterization of 10 microsatellite markers for G. sericea. Enriched libraries were established from size selected (300-750 bp) genomic DNA ligated into the Hind III site of a pUC19 plasmid and enriched using magnetic bead capture (CPG, Inc., Lincoln Park, New Jersey) with biotin-labelled CA(15), Biotin-GA(15), Biotin-AAC(12) and Biotin-TAGA(8). Microsatellite-containing clones were identified from two di-nucleotide and two tri-nucleotide repeat libraries. Plasmids from 96 positive clones were sequenced and primers designed for microsatellite-containing clones using DesignerPCR version 1.03 (Research Genetics, 
Table 1 Characteristics of ten polymorphic microsatellite loci in Glionnetia sericea

\begin{tabular}{|c|c|c|c|c|c|c|c|c|c|}
\hline Locus & GenBank accession. No. & Primer sequence $\left(5^{\prime}-3^{\prime}\right)$ & Repeat motif & $\begin{array}{l}\text { Size range } \\
\text { (bp) }\end{array}$ & $\operatorname{Ta}\left({ }^{\circ} \mathrm{C}\right)$ & $A$ & $H_{\mathrm{o}}$ & $H_{\mathrm{e}}$ & $P I C$ \\
\hline B6 & JN377940 & $\begin{array}{l}\text { F: CCACCCTGGAAAGAAAGTG } \\
\text { R: GGGACTGTTGCTACTGAAGG }\end{array}$ & $(\mathrm{AG})_{18}$ & $239-264$ & 56 & 11 & 0.76 & 0.79 & 0.76 \\
\hline C104 & JN377941 & $\begin{array}{l}\text { F: CAGCCATCAGAACCTTACA } \\
\text { R: ATAGCCGACCCCACATAG }\end{array}$ & $(\mathrm{CAA})_{8}$ & $131-143$ & 56 & 3 & 0.44 & 0.46 & 0.38 \\
\hline A104 & JN377942 & $\begin{array}{l}\text { F: GCGATTTTGTTCAGGGTC } \\
\text { R: ATTTTAGCAGACACAGGATGAC }\end{array}$ & $(\mathrm{CA})_{18}$ & $161-183$ & 56 & 6 & 0.49 & 0.66 & 0.61 \\
\hline$B 110$ & JN377943 & $\begin{array}{l}\text { F: TCССТCСТATGAAAATTACTG } \\
\text { R: TATCCCTTTAGCATTGGAACA }\end{array}$ & $(\mathrm{AG})_{13}$ & $219-227$ & 56 & 5 & 0.70 & 0.73 & 0.68 \\
\hline B102 & JN377944 & $\begin{array}{l}\text { F: ATTAGCATCTAACGCACGATA } \\
\text { R: AGCAAAGCCATTACTTGTAGTC }\end{array}$ & $(\mathrm{TC})_{5}(\mathrm{CT})_{14}$ & $295-315$ & 56 & 4 & 0.33 & 0.39 & 0.35 \\
\hline$C 10$ & JN377945 & $\begin{array}{l}\text { F: ATAGCCGACCCTACATAGTGG } \\
\text { R: TGATTGCTGGAGTACCTTCTG }\end{array}$ & $(\mathrm{GTT})_{7}$ & $211-217$ & 56 & 3 & 0.24 & 0.28 & 0.26 \\
\hline$C 12$ & JN377946 & $\begin{array}{l}\text { F: TGGTGGAACTACTTGAGCA } \\
\text { R: TTGCGTTAGGTTGACAGC }\end{array}$ & $(\mathrm{ACA})_{7}$ & $138-148$ & 56 & 3 & 0.30 & 0.27 & 0.24 \\
\hline A106 & JN377947 & $\begin{array}{l}\text { F: CACCAACCAAATTAACAAGAT } \\
\text { R: GTCAGCACAAATCAATCTATCC }\end{array}$ & $(\mathrm{CA})_{13}$ & $194 v 222$ & 56 & 12 & 0.78 & 0.82 & 0.80 \\
\hline B109 & JN377948 & $\begin{array}{l}\text { F: GCAAAATCAAATCAGGTGAC } \\
\text { R: GCTCCAAAGAGAGAAGAAAAG }\end{array}$ & $(\mathrm{CT})_{18}$ & $108-130$ & 56 & 11 & 0.58 & 0.82 & 0.79 \\
\hline C105 & JN377949 & $\begin{array}{l}\text { F: CTGTCCTTTTCACATTGTTCTG } \\
\text { R: GCGAAACATCATCCATATAGC }\end{array}$ & $(\mathrm{CAA})_{6}$ & $128-134$ & 56 & 3 & 0.28 & 0.48 & 0.37 \\
\hline
\end{tabular}

$F$ forward primer, $R$ reverse primer, $T_{a}$ annealing temperature, $A$ mean number of alleles, $H_{o}$ observed heterozygosity, $H_{e}$ expected heterozygosity, PIC Polymorphism information content, 81 individuals were analysed for each locus

Inc), of which a subset were tested for polymorphism. The ten most promising loci were optimized. All primers were labeled using an M13-tag at the $5^{\prime}$-end following Schuelke (2000) (Table 1). Polymorphism of the ten selected primers were evaluated using 81 adult trees of $G$. sericea samples collected from seven different sites on Mahé.

Leaf genomic DNA was extracted from G. sericea $(n=211)$ using the QIAGEN DNeasy Plant Maxi Kit, following the manufacturer's protocol. PCRs for the M13 primers were carried out in $10 \mu \mathrm{l}$ reactions with $2 \mu \mathrm{l}$ of $1 \times$ PCR buffer (Promega colorless Flexi GoTaq PCR buffer), $15 \mathrm{mM} \mathrm{MgCl}_{2}, 0.2 \mu \mathrm{M}$ dNTPs, $0.2 \mu \mathrm{l}$ of the $0.04 \mu \mathrm{M}$ M13 forward primer, $0.8 \mu \mathrm{l}$ of the $0.16 \mu \mathrm{M}$ reward primer and $0.8 \mu \mathrm{l}$ of the $0.16 \mu \mathrm{M}$ M13 primer, $0.025 \mathrm{U}$ Taq polymerase (Promega), and $2 \mu \mathrm{l}$ DNA template (c. $10 \mathrm{ng}$ ). Cycling conditions were as follows: $1 \times\left(95^{\circ} \mathrm{C}\right.$ for $\left.15 \mathrm{~min}\right)$, $30 \times\left(95^{\circ} \mathrm{C}\right.$ for $30 \mathrm{~s}$, primer-specific temperature $\left(56^{\circ} \mathrm{C}\right)$ for $45 \mathrm{~s}, 72^{\circ} \mathrm{C}$ for $\left.45 \mathrm{~s}\right), 8 \times\left(95^{\circ} \mathrm{C}\right.$ for $30 \mathrm{~s}$, primer-specific temperature $\left(53^{\circ} \mathrm{C}\right)$ for $45 \mathrm{~s}, 72^{\circ} \mathrm{C}$ for $\left.45 \mathrm{~s}\right), 1 \times\left(72^{\circ} \mathrm{C}\right.$ for 30 min) (Table 1) carried out in a Bio-Rad Dyad Cycler. We used an ABI3730 for genotyping and Genemapper 3.5 software (Applied Biosystems) for fragment analysis.

The number of alleles and deviations from Hardy-Weinberg equilibrium (HWE) were generated using GenAlEx 6.2 (Peakall and Smouse 2006). The polymorphism information content (PIC), observed and expected heterozygosities was calculated in Cervus 3.0 (Kalinowski et al. 2007). Linkage disequilibrium was implemented in GENEPOP (Raymond and Rousset 1995). All ten loci were polymorphic with 3-12 alleles and a total number of 61 alleles detected over all populations for $G$. sericea. Observed heterozygosity values ranged from 0.24 to 0.78 and expected heterozygosity from 0.27 to 0.82 . There was no evidence for scoring error due to stuttering, no evidence for large allele dropout and no evidence for null alleles according to microchecker 2.2.3 (Van Oosterhout et al. 2004). Significant deviations from HardyWeinberg equilibrium (HWE, $P<0.05$ ) were detected in loci B109 and C105. No significant linkage disequilibrium was detected after Bonferroni correction suggesting that all 10 loci segregate independently of each other. The results indicate that these 10 primers will provide a valuable tool for evaluating genetic diversity and the reproductive ecology of this rare tree species.

Acknowledgments We thank Didier Dogley (Department of Environment, Seychelles) and Denis Matatiken (National Parks Authority, Seychelles) for providing export and collection permits, respectively, as well as valuable advice and administrative support. Many thanks to Terence Valentin, Damien Doudee and James Mougal for crucial assistance in the field. We acknowledge the Genetic Identification Services (http://www.genetic-id-services.com) for the development of 
the microsatellites. Fragment analysis was conducted using the sequence facilities of the Genetic Diversity Centre of the ETH Zürich. The research was approved by the Seychelles Bureau of Standards and received funding from ETH Zürich, Ecosystem Management group (grant number ETH-07 08-01).

\section{References}

Daehler CC, Denslow JS, Ansari S, Kuo C (2004) A risk-assessment system for screening out invasive pest plants from Hawaii and other Pacific Islands. Conserv Biol 18:360-368

IUCN (2011) IUCN Red list of threatened species. Version 2011.1. www.iucnredlist.org. Downloaded on 05 Sep 2011

Kaiser-Bunbury CN, Valentin T, Mougal J, Matatiken D, Ghazoul J (2011) The tolerance of island plant-pollinator networks to alien plants. J Ecol 99:202-213
Kalinowski ST, Taper ML, Marshall TC (2007) Revising how the computer program CERVUS accommodates genotyping error increases success in paternity assignment. Mol Ecol 16:10991106. doi:10.1111/j.1365-294x.2007.03089.x

Peakall R, Smouse PE (2006) GENEALEX 6: genetic analysis in excel. Population genetic software for teaching and research. Mol Ecol Notes 6:288-295

Raymond M, Rousset F (1995) GENEPOP (version 1.2): population genetics software for exact tests and ecumenicism. J Hered 86: $248-249$

Schuelke M (2000) An economic method for the fluorescent labeling of PCR fragments. Nat Biotechnol 18:233-234

Van Oosterhout C, Hutchinson WF, Willis DPM, Shipley P (2004) MICRO-CHECKER (ver. 2.2.3): software for identifying and correcting genotyping errors in microsatellite data. Mol Ecol Notes 4:535-538 